\title{
Multiple Shocks and Slum Household Economies in South India
}

\author{
Barbara Harriss-White, Wendy Olsen, Penny Vera-Sanso and V. \\ Suresh $^{1}$
}

September 2012 re-submitted to Economy and Society (Special Issue edited by Stuart Corbridge and Alpa Shah)

Keywords: ageing, household, India, slums, growth, shocks

\footnotetext{
${ }^{1}$ Acknowledgements:

This is a reduced version of the paper for the Conference on 'The Hidden Contribution of Older People: Rethinking Age Poverty Opportunity and Livelihoods', Centre for Law, Policy and Human Rights Studies and the Department of Humanities and Social Sciences, IIT Madras, $19^{\text {th }}$ and $20^{\text {th }}$ March, Chennai, 2010. We wish to thank Marlia Hussain, Henry Joe and Arul George for their field research in difficult conditions - without which the desk research would not have been possible. We wish to thank the two referees for meticulous comments. Barbara Harriss-White also wishes to thank IEDES, Paris-1, for the visiting professorships providing her with the space to complete this paper. The research is part of the New Dynamics of Ageing initiative, a multidisciplinary research programme supported by Arts and Humanities Research Council (AHRC), Biotechnology and Biological Sciences Research Council (BBSRC), Engineering and Physical Sciences Research Council (EPSRC), Economic and Social Research Council (ESRC) and Medical Research Council (MRC), The project comes under a grant (RES-352-25-0027) entitled "Ageing, Poverty And Neoliberalism In Urban South India", directed by Penny Vera-Sanso, Birkbeck College, London, 2009. Contact p.verasanso@bbk.ac.uk.
} 


\title{
Multiple Shocks and Slum Households in South India
}

\begin{abstract}
This research uses a fresh perspective to trace the impact of multiple economic, financial and environmental shocks on the 'underbelly' of slum dwellers in the South Indian city of Chennai over the period November 2008 to May 2009. It examines the effects of a concatenation of events scaled from the global to the local: consisting of economic shocks (speculation in financial, fuel and food markets) and extremes of rainfall and temperature on a cross-section of the urban poor (differentiated by age and gender) taking in household dynamics and work status.. The paper also traces the rapidity with which these shocks transfer from the global economy to slum settlements. The method involved 12 month recall over the 6 month survey period during the shocks and their aftermath, a comparison of emic and etic measures of economic wellbeing and the comparative use of mixed methods. This research is also the first application of Qualitative Comparative Analysis to slum conditions.
\end{abstract}

Keywords: QCA, slums, shocks, India, informal economy, ageing, poverty, mixed methods 


\section{Multiple Shocks and Slum Households in South India}

The geographer Mike Davis (2004) - extrapolating from current trends - has predicted that over the next generation $95 \%$ of the 'final build-out of humanity'(ibid, p6) will be positioned in the cities of developing countries, already pock-marked with sites, swathes and peripheries of the unregulated and poor quality housing known as slums. Three quarters of this 'final' urban revolution will be in slums. On a world scale, Davis finds that these settlements are un-related to the capacities of specific cities to provide work. Rather they reflect the general failure of stable employment possibilities anywhere else, together with the state's incapacity to supply secure titles to land, housing, energy and water. Many states are also unable to cope with solid and liquid urban waste. In all respects India conforms to Davis' findings. Of the 377 million people thought to live in India's 53 million-plus cities and 8,000 towns, 93 million are estimated to inhabit slums. ${ }^{2}$ These settlements are reckoned to be growing at 5\% per year - a factor 3.8 times greater than the population as a whole.

In India the concept of 'slum' is well-established in both technical and legal terms. Technically slums are residential sites with poor infrastructure. ${ }^{3}$ Legally 'notified slums', sites classified by state and local government as slums, have greater legal protection and access to state resources to notified slum-dwellers than to those in un-notified slums. ${ }^{4}$

\footnotetext{
${ }^{2}$ Government of India, Press Information Bureau, 2012: http://pib.nic.in/newsite/erelease.aspx?relid=71733

${ }^{3}$ According to the Government of India 2011 Census a slum is "a compact area of at least 300 population or about 60-70 households of poorly built congested tenements, in unhygienic environment usually with inadequate infrastructure and lacking in proper sanitary and drinking water facilities".http://www.indiaonlinepages.com/population/slum-population-in-india.html

${ }^{4}$ The Slum Areas (Improvement and Clearance) Act 1956 provided for the improvement and clearance of slum areas and for the protection of residents from eviction, requiring that the state rehouse slum dwellers
} 
Slums are sites of poverty, yet they are also marked by inequality and differentiated economic and social status. And while higher concentrations of Dalit and "most backward class" ("MBC") people ${ }^{5}$ may be found in slums than other areas, slums are not exclusively made up of these lower castes, nor are urban Dalits and MBCs to be found exclusively in slums. Economically productive work takes place in slums, some of which is integrated into local, national and even international markets. Slum dwellers will also work away from slum sites. So while slum household economy is a meaningful concept, there is no such thing as a slum economy. Now that India's formal economy has become linked to the global economy through liberalization and deregulation it has also harnessed the informal, unregistered economy to global markets, ensuring in the process that risks are transferred downwards and profits upwards. ${ }^{6}$ Slum dwellers are left among the most vulnerable and least rewarded producers in the bloating underbelly of the global economy. Far from being marginal, the key feature of slum populations is their marginalization from the fruits of their labour. This paper explores the impact of the financial crisis on slum dwelling people, but, unlike other studies of financial crises, it

in non-slum conditions on the same site. The Corporation of Chennai first notified 1,202 slums in 1971 and added 17 more slums in 1985. The failure to notify more slums is one of the foci of Chennai slum dweller associations' current campaigns. Increasingly state and local governments are coming under pressure from central government and national institutions to reduce the minimum number of household for slum notification from 60 households to twenty. In the context of India's new 'slum-free cities' Rajiv Awas Yojana programme, following on from the UN's Cities without Slums campaign, notified slum status is not providing the legal protection it once did (PUCL 2010; see also Gilbert 2007), yet 'slum' as a technical and legal term that places the burden of providing minimum housing standards on the State retains deep political salience for slum dwellers.

5 The Indian Constitution defines the government's responsibilities to 'Backward Classes' which include Scheduled Castes (Dalits) and Scheduled Tribes as well as 'Other Backward Class' (OBC), made up of caste groups considered to fulfil the constitutionally defined criteria of being 'socially and educationally backward' (Article 340, Constitution of India, 1949) (Revankar, 1971). Following a Supreme Court decision a permanent National Commission for Backward Classes was set up in 1994.

${ }^{6}$ Harriss-White, 2009 
explores this impact within a real-world framework that includes other coinciding, interconnected and interlocking shocks: in this case environmental shocks and instabilities in global oil and food markets

In the literature on Indian slums two aspects of the household economy have been strikingly absent. The first is the role of interlocking shocks and crises which may trigger downward mobility and reinforce marginalisation. The second is the economic contribution of ageing slum-dwellers. In this paper, we combine the two, relating a series of shocks on the one hand to the life worlds of impoverished workers, of slum-dwellers and of ageing citizens on the other. Our findings are more nuanced than most quantitatively-based economic studies. And before we develop our general themes in this paper, we start by introducing the specific context of the field research project which developed from 2007-10. We then introduce the repertoire of shocks that hit the Chennai slums and the new analytical methods we used to trace their effects on individuals and households.

\section{Introduction: the city, its slums and the 'accumulated disadvantage' of their workers}

With a population of 72.1 million, Tamil Nadu is the sixth largest state in India. According to the 2011 census, the proportion of its urban population to the total is $48 \%$ (significantly higher than the national Indian urban average of $31 \%$ ). This urban population is spread across six main cities, with Chennai city's official population, at 4.7 
million, accounting for $13.5 \%$ of the state's urban population. The Chennai Metropolitan Area, comprising the 8.9 million people living in the city and its extensive suburbs (Govt of India, 2011), is not only the fourth largest metropolitan agglomeration in India but also one of the fastest-growing metropolitan economies. This is due in considerable measure to its skilled manpower, its FDI-friendly environment and the flourishing Information Technology/Information Technology Enabled Services (IT/ITES) related industry in the city and its hinterland.

Chennai may be FDI-friendly, but, it is also one of the most densely populated cities in India. With 26,903 persons per sq. km as against Tamil Nadu's overall population density of 555, Chennai city is by far the most densely populated district, a differential maintained over three decades. From 2001-2011 Chennai city's density grew by some $7.7 \%$ - mainly due to migration from inside and outside Tamil Nadu. As a result of migration and the by-product of prestigious growth, Chennai has India's fourth largest population of slum dwellers, representing at least $26 \%$ of Chennai's population, with an average household size of 4.5 members (Chandramouli, 2003). Compared with non-slum areas, slums have higher concentrations of people who are constrained by a reinforcing set of deprivations including low caste, less education, insecure work, limited economic resources, unenforceable rights, low and irregular incomes and malnutrition and other health deficits. These result in what is glossed here as 'poverty', the main characteristic being heightened vulnerability that in turn exposes people to deeper deprivation. While the best-researched vulnerability is to ill-health (Kabir and Rahman, 2000; Pryer , 2003) others are policy-induced. The city's beautification, slum clearance and road building 
schemes raise land values in beautified tracts and lead to the extrusion of inner-city slum dwellers to the suburbs, in a process of cleansing the city of the urban poor that is now widespread in all of India's largest and densest cities. ${ }^{7}$

Chennai's slums are of long-standing, many founded by migrants in the 1940s on what was unused public or private land that was low-lying and flood-prone. With rising densities, the shortage of affordable housing and the lack of opportunities elsewhere, city slum-land and property have long been informally privatized and commercialized. The resulting physical and economic pressures on slum-dwellers have major impacts on everyone's life but in particular they disadvantage ageing workers. In mixed-methods research undertaken by Vera-Sanso and V Suresh between 2007-10 in a randomly sampled Chennai slum population of 800 households (containing 3,474 people) and from the monitoring of a busy central Chennai market for 30 months - and drawing on the theoretical ideas of Dannefer (2003) - Vera Sanso (2010) identified these pressures and developed a theory of the accumulation of disadvantage over a lifetime's exposure to them. Disadvantage accumulates progressively due to a set of factors, among which the most important are:

- Lack of rights to work, at work and obstruction to labour organisation;

\footnotetext{
${ }^{7}$ Relocating slum settlements on the urban periphery is the standard recourse of urban planning when implementing infrastructural changes. In recent years a number of highly controversial policies including the Jawalharlal Nehru National Urban Renewal Mission, funded by the World Bank, and its successor the Rajiv Awas Yojana are producing much wider slum relocations that severely hit incomes and reflect what is essentially an attempt by the State, capital and the middle classes to cleanse the poor from India's major cities (see Chatterjee 2004 on Kolkata, formerly Calcutta; Rajagopal 2001, Fernandez 2004, Anand 2006, Anjaria 2006, on Mumbai, formerly Bombay and Bhan 2009 on Delhi). The slum relocation programme has not, as yet, affected the five slums on which this paper is based.
} 
- Changes in the structure of the urban economy in which their labour is displaced and demand for their skills evaporates;

- Changes in slum land values (which rise) and urban land use (malls, offices and new gated residential complexes);

- Removal of street markets by local government;

- Relocation of housing to sites from which previous work is inaccessible;

- Wage goods inflation;

- The privatisation of basic needs and essential infrastructure (further increasing household budgets);

- Growing credentialism in labour markets (replacing recruitment by affinity or ascribed status by raising minimum standards for labour market entry by slum children - and thus raising the cost of education and socialisation to work);

- Absence of entitlement to social security provision for maternity, sickness, or unemployment.

- Thresholds for pensions entitlement which exceed life expectation; restrictive eligibility; access procedures which self-deny the poorest; stingy provision and rationed pension allocations.

Not only do these factors threaten self-provisioning by ageing workers, they threaten filial support as well because of the accumulation of disadvantage in the next generation. India's inadequate old age support has a disproportionate impact on women because women outlive men: for the slum population of people aged over 50 there are 1.5 times as 
many women as there are men in the sample (see also IIPS, 2008). ${ }^{8}$ Throughout the lifecourse, gender discrimination (in property relations, in several dimensions of human development, in wages and returns to self-employment) leaves older women relatively more deprived of resources than ageing men (Vera-Sanso, forthcoming a). Field research shows that almost half the male slum-dwellers aged 75-9 in Chennai had younger working wives (Vera-Sanso, 2010). Not only are women saddled with a double burden of subsistence and household reproductive work but as they grow older they also tend to become the primary earner while their deprivation deepens with advancing age. With India's large and rapidly increasing over 60 population, the question of the impact of shocks on ageing people is timely. ${ }^{9}$

\subsection{Threats, Shocks and the Slum Household Economy}

Over and above the relations resulting in the accumulation of disadvantage among ageing workers, among which episodes of ill health or the onset of incapacitating disability are generally found to be the most economically damaging ${ }^{10}$, the household economies of slums have recently been hit by a series of severe economic and environmental hazards. Without income smoothing safety nets from social security or savings, household reactions to a shock will incur both direct costs and opportunity costs - the latter being the income foregone while crippled by an unexpected event and the terms and conditions

\footnotetext{
${ }^{8}$ Chennai slums have a female to male sex ratio that at 968 is higher than the non-slum population's sex ratio at 945 (Chandramouli, 2003).

${ }^{9}$ In 2001 over 70 million people were aged 60 and over, representing $6.9 \%$ of the total population,; projections for 2011 and 2026 place the $60+$ population at $8.2 \%$ and $10.2 \%$ respectively (Govt of India, 2006)

${ }^{10}$ Erb and Harriss-White, 2003
} 
of a bailing-out debt otherwise not needing to be contracted. Several trajectories are possible. A shock may initiate downward mobility. Or it may generate a crisis - a turning point - after which the household recovers, in which case poverty may be transitory. Alternatively the hysteresis effect of a shock may knock the household permanently offcourse into poverty quagmires. Our understanding of shocks developed as the research progressed in the Chennai slums. It is laid out here in the sequence of discovery.

\subsubsection{The Global Financial Crisis and Impact on Informal / Slum Household Economy}

The 2008 crisis in global finance was a shock to mainstream economics, which had famously not predicted it. ${ }^{11}$ Nor was there theory about its impact on the informal nonstate-regulated economy or the household economy of slum-dwellers. The late Peter Gowan's (2009) political economy explanation for the financial crisis is a useful backcloth to a summary of what is known about its impact on India's informal economy. Gowan situates the most destructive speculative bubble - US housing - as part of a regular series of bubbles necessary to a new Wall Street-based financial system. This is dominated by an oligopoly of banks and their satellites which have been permitted to speculate on future assets and collateralised debts. It is this integrated structure which collapsed in 2007-8, immediately paralyzing lending and debt-fed consumption alike. ${ }^{12}$

\footnotetext{
${ }^{11}$ An array of views has been tabled ex post, ranging - to name but a few - from contagion from sub-prime lending, through business cycle explanations, misconceived expectations, mis-management of reserves, Hayekian instability, to moral hazard in the financial sector, incompetence and stupidity among policymakers. See respectively Bouchard, 2008, Holland, 2009, Soros, 2008, Ackerman, 2008, Edmund Phelps and Joseph Stiglitz (both December 2008, presentations at the Cornell-IHD conference on Amartya Sen's $75^{\text {th }}$ birthday New Delhi - henceforth 'Sen-conf').

${ }^{12}$ This collapse was triggered by the realisation that 'the suppliers of credit funding...had no way of knowing how much of the mountain of collateralized debt obligation was junk' Gowan, (2009).
} 
While, the impact on India's formal economy was felt directly by the financial system, only a few Indian banks were directly exposed. Even so, it suffered rapidly from the atrophication in lending, outflows from the stock market and shrunken flows of remittances. $^{13}$

The major impact in India, however, was felt in the real economy where oil and food price instabilities in the formal, registered sectors had already generated inflation, and slowed corporate investment with a destructive impact on growth. The Planning Commission's predicted $9-11 \%$ rate for $2008-9$ was reduced to $6.7 \%$. It was just $6 \%$ in 2011. ${ }^{14}$ The demand for exports declined during 2009 and India's IT exports, already under pressure in 2008, were expected to be badly hit (UNCTAD, 2009: 19). The manufacturing growth rate halved from November 2007 to 2008 (Govt of India, 2009). Lack of export credit hit the smallest export firms disproportionately while the depreciation of the Rupee hit imported components. India's exports are relatively labourntensive (Sardar, 2008) - textiles, handloom garments, leather, gems and jewelry, metalware, carpets, agricultural products (spices, basmati rice and sea-food) together with IT/BPO services. In fact the main impact of the fall in demand for India's exports has been shown to be on employment, with even small declines in exports leading to hundreds of thousands of lost jobs (UNCTAD, 2009: 39). Most livelihoods in the affected sectors are in the informal economy.

\footnotetext{
${ }^{13}$ ADB, 2009. Keen (2011) presents a wide-ranging theory consistent with Gowan's critique.

${ }^{14}$ Ahluwalia (Sen-conf). It rallied to 9.4 in the second quarter of 2010 but has sunk continuously to $6.9 \%$ at the end of 2011 http://www.tradingeconomics.com/india/gdp-growth accessed on 15.1.12
} 
By December, 2008, 100,000 jobs were known to have been lost in the diamond industry in Surat and 750,000 in power loom weaving (Alagh, 2008). A survey of 11 states in October-December 2008 recorded significant drops in capacity in the automobile, metals and export industries with about 500,000 job losses in the automobile, transport and gem/jewelry sectors. The rate of job losses in the informal sector ('contract work') was estimated to be 6 times greater than in the formal sector (Govt of India, 2009). WIEGO's responsive research of 14 urban locations in 10 countries across Africa, Asia and Latin America, including India, during 2009 showed a rapid and dramatic drop in demand and prices for recyclable waste from the informal economy - metals, cloth, plastics and glass - more insecurity in contracts and greater delays in payment in informal textiles and garments production and reductions in days worked and wage rates in the construction industry (WEIGO, 2009). ${ }^{15}$

It follows from this that the informal economy in Chennai's slums was threatened by the Wall Street crisis through four pathways. First, a shortage of formal business credit has a negative multiplier effect on informal credit and hampers informal transactions and inventory holding. A credit shortage can also raise real informal interest rates. ${ }^{16}$

Second, price rises resulting from the continuing depreciation of the Rupee affect urban consumers through the rising costs of imported goods. Demand would then shift towards local substitutes. As the field research progressed, however, it was apparent that not all

\footnotetext{
${ }^{15}$ WIEGO does not distinguish petty commodity producers from other labour. By comparison our Chennai study found that economic crisis, food and fuel price hikes and environmental shocks significantly reduced demand for informal sector manufacturing, trade and services by the formal sector and by people working in the formal and informal economies, The 2010 restudy of 13 of WEIGO's sites found that persistent unemployment and underemployment in the formal economy continued to drive new entrants into informal employment and a persistent lag in recovery for informal workers (Horn, 2011).

${ }^{16}$ The Asian Development Bank has documented formal credit shortages in India in 2008-9. ADB, 2009.
} 
price hikes that battered the slum-dwellers related directly to the global crisis. Back in the domestic economy, food prices - basic to all budgets - were spiking. exposure to volatile international prices, mediocre to stagnant performance in food and agricultural production (except in a few northern states) and constraints imposed by the central government on the operation of the Public Distribution System had combined to shove a widening wedge between farm gate wholesale prices and destination wholesale prices and also between the latter and retail prices. Food price inflation has not returned to the status quo before the global speculative price spike in $2007-8^{17}$; nor are food prices stable. Food price inflation was at $17.5 \%$ in the year between November $2008-9$ and the wholesale price index rose at $17.9 \%$ between February 2009-10, remaining almost as high until the end of 2011. ${ }^{18}$ There are four food zones in India. Chennai is in the southern zone. Here the average retail price of rice shot up by $69 \%$ in the two years to January 2010. That for wheat/atta increased by 13\%; that for sugar by $109 \%$ (Ghosh and Chandrasekar, 2010). While the price of rice distributed through the Public Distribution System (PDS) had been promptly reduced to Rs1 per kg by the state in October 2008, given the rapid and pervasive nature of entitlement shortfalls, slum dwellers' budgets were squeezed by the costs of food purchased outside their PDS rations. ${ }^{19}$

The third pathway is that of the indirect employment multiplier. A reduction in activity in the construction industry, IT related services and other exports affects the hourly and

\footnotetext{
17 This was itself a concatenation event involving among other factors : poor harvests worldwide, land competition between food and biofuel, conversion of food to biofuel, rising petro-based input costs; plant and animal diseases, and speculation in food futures markets. India stopped grain exports.

18 Times of India March $4^{\text {th }} 2010$; India Awake Dec $16^{\text {th }} 2009$; https://www.dbsvresearch.com/research/DBS/research.nsf/(vwAllDocs)/FD1125D60215CB9D4825782200 286311/\$FILE/IN_Food\%20inflation\%20is\%20demand-driven_24\%20Jan\%2011.pdf

${ }^{19}$ The Public Distribution System is the policy instrument protecting the calorie supply of people below Poverty Lines.
} 
weekly earnings of wage workers such as kuulies (those working on casual arrangements as labourers) as well as service providers. Most cities in India had a rapid downturn in construction investment in 2008-9, leading to a reduction in new investment, a slowing of development and negative multipliers in transport. The closure of big building sites in Chennai itself also resulted in workers from local sites crowding into the even more insecure, intermittent lower reaches of the construction industry.

By early 2009, field research in Chennai slums had revealed that the negative multiplier of the decline in exports not only reduced demand and finance for construction, it also reduced demand for auto- transport, and domestic services, street vending, laundry and ready-made food supplies. In order to try to increase household incomes, households dependent on unskilled wage labour put more people into the labour market, seeing such responses as a measure of their own downward trajectories. ${ }^{20}$

Fourth, given changes to the second and third pathways, families with high dependentworker ratios and a larger proportion of people in middle age and older may face rising entry barriers to work in not just old forms (age) but new ones (school diplomas) (VeraSanso forthcoming b). This was particularly the case for casual day-rate and piece-rate skilled and semi-skilled construction work.

\subsubsection{Environmental Shocks and their Impact on the Informal Economy and Slums}

\footnotetext{
${ }^{20}$ In addition to putting more people onto the labour market, 'difficulties finding work' were mentioned by some respondents, so we explore and test whether 'workers' suffered worse during 2008-9 than 'selfemployed' (i.e. trading and business) households. The study found that in addition to increasing the worker-dependent ratio there were widespread concerns about rising education costs and evidence of some withdrawal of girls from education. See also Horn 2011.
} 
Other shocks were weather related. Whether these are accurately conceptualised as 'shocks' when they happen fairly regularly may be debated; the point is that their impacts are unavoidable, they are severe, they increase daily costs of survival for, and reduce the incomes of, most slum households. We discuss them here under temperature and rainfall.

In South India, high temperature (especially when combined with humidity) grinds outside activity to a virtual halt. The reduction in consumer demand and capacity to work - even for auto-rickshaw drivers with inadequate insulation from the glare and heat affects livelihoods, reducing the incomes of those depending on outside work. The exceptions are of sales of water, fruit juice and water-laden fruit such as melon and mango, where the off-season is in the cooler months. ${ }^{21}$ While 2008-9 did not have higher monthly maximum temperatures or lower minima than other years in the preceding decade ${ }^{22}$ maximum mean monthly temperatures have risen steadily over the period 20059 from 28.8 degrees to 31 . April and May are inexorably hot: May 18th 2008's average exceeded 42 with humidity above $58 \%$ and April $18^{\text {th }} 2009$ 's average exceeded 39 degrees at over $69 \%$ humidity. These are severe weather conditions for human beings. ${ }^{23}$

\footnotetext{
${ }^{21}$ http://www.thehindu.com/news/cities/chennai/article3353857.ece. To deal with the 2012 heat wave the Government of Tamil Nadu supplied lemonade to traffic police to prevent heat stroke. By comparison slum dwellers' access to water, especially energy-dense, sugared water, is very much more constrained especially while working away from home.

${ }^{22}$ The highest daily average was 45 in 2003 and the lowest was 17.9 in 2004.

http://www.kea.metsite.com/monthly_summaries.htm

${ }^{23} \mathrm{http}: / / \mathrm{www}$, thaiindian.com. These averages underestimate temperatures in the city centre because the Meenambakam weather station is in a cooler periphery of the city. http://www.thehindu.com/news/cities/chennai/article3494345.ece The slightly lower 2012 heatwave is described as bringing Chennai 'to its knees' - environmental insults are particularly severe for the quarter of people living in slums, without the benefit of regular water, electricity generators, air condition vehicles and so on..
} 
Rainfall threatens non-agricultural urban livelihoods and domestic economies directly and indirectly through quantity and distribution. Low rainfall affects dry season water tables and triggers food price inflation due first to speculation on anticipated harvest shortfalls - and then to rises on actual shortfalls. Mal-distributed rainfall leads to flooding not only from overflowing rivers in spate but also from clogged drains, collapsed culverts and burst sewage mains. Chennai's drainage is built on the colonial pattern of using natural gradients. But these gradients have been disturbed with the re-laying of roads. New drains have been put in badly, impeding drainage. At $1181 \mathrm{~mm}$, while the rainfall for 2008-9 was the second lowest in the previous decade, Chennai slums fell prey to the outer tendrils of cyclone Nargis in May 2008 (which devastated the south of Myanmar) and much more severely to the clutches of cyclone Nisha in Nov-December 2008. Some people in slums lost their homes; others had to stay with relatives in cramped quarters for long periods; for yet others it was impossible to leave home. Income was threatened. Damage needed repair, ruined possessions and tools needed replacement, sickness added to costs. 'Demand' - in fact need - for cash doles and relief packages was such that it had to be rationed by the Tamil Nadu Government. ${ }^{24}$ Many of the urban poor are trapped in seasonal cycles of extreme events and environmental insults which lower incomes and raise costs.

On discovering that the domestic economy of slum households had been affected by all the insults discussed above, that is: contraction of credit, slumps in demand, food and fuel price hikes, and extreme weather conditions, and were arguably less able than other classes to mitigate their consequences, it was clear that attempts to disentangle these

${ }^{24}$ http://www.tn.gov.in/gorders/rev/rev_e_738_2008 
shocks and their dynamics in order to make detailed cause-effect analyses of every pathway would be theoretically to miss their cumulative and interactive quality and practically to be impossible. In etic, cause-effect terms, the set of shocks constitute a series of multiple causes with multiple effects. In emic terms of historical experience, these shocks and the relationships they disturb were experienced as a concatenation process.. ${ }^{25}$ What follows here then is an analysis of the impacts of these combined environmental and economic insults.

\section{Survey Methods, Evidence and Initial Results}

While other contributions to this collection examine specific industries and sectors (see Parry, Bear, this volume) our research explores the impacts of varied shocks from November 2007 to May 2009 on the underbelly of Chennai's slum dwellers and their livelihoods. Five slums had been chosen, two of 50 years standing and previously researched by Vera-Sanso together with two founded in the 1940s in the old centre of Chennai and one comparatively recent slum abutting the new IT corridor on the periphery. The economic crisis hit India after we had spent a year in these slums. completing an 800 household face to face survey. and were undertaking multiple in-depth interviews with 179 households (see Appendix 1 for methods). A subset of the 179 households was identified for three further rounds of longitudinal surveys covering an 18 month period spanning November 2007 to May 2009.In face to face surveys, respondents were asked to compare their economic circumstances in November 2008 with that of

\footnotetext{
${ }^{25}$ Slum dwellers' awareness of their proximity to economic collapse was amply demonstrated in some of their assessments and measures of their economic status; for some cutting back their quantity and nutritional quality of food was classed as 'staying the same' and for others becoming dependent on relatives was classed as having 'gone up'.
} 
November 2007, January 2009 with January 2008 and so on. We gathered evidence for two 'ways of knowing' about the experience and impact of the set of shocks. Not only were detailed economic data on income, assets, savings, debts and budgets collected which form the raw material for orthodox economic analysis of poverty trajectories and vulnerabilities (Erb and Harriss-White, 2003; Hyat, 2001), but informants' own experiences of improvement, deterioration or stasis in their 'economic conditions' were also elicited along with the criteria they used for their evaluations and their own narratives of the causes of their trajectories. Certain respondents also wanted to discuss the changes between one round of survey and the next. This 'point to point' comparison along with informants' explanation for change or its lack helped to overcome the 'noise' of seasonal, weather- and festival-related variations in their work- and householdeconomy. It enabled the impact of unusual seasonal and economic variations to be revealed. $^{26}$ Further, the self-assessment provided insight into people's economic circumstances that metric methods could not achieve. 'Economic circumstances' is a well-understood concept involving the balance between assets, income and savings on the one hand and liabilities and expenditure on the other; narratives about economic circumstances revealed that even in those households where income had not fallen and spending on food appeared to be unchanged people met price hikes by cutting out vegetables and other protein sources and dropping a meal - leaving some eating once a day. $^{27}$

\footnotetext{
${ }^{26}$ This paper draws only on the economic surveys. For the larger survey and qualitative research, see VeraSanso, 2010, and forthcoming.

${ }^{27}$ Some informants measured their decline by having to start eating beef, which is a cheaper and highly stigmatised source of protein for caste Hindus.
} 
To explore how the impact of shocks on livelihoods translated into household experiences of shock, each household was allocated to a work status group and an industrial sector according to their major economic base - understood by respondents either as the source of the largest income or as the longest-standing source of income. ${ }^{28}$ The data represent a purposive sample drawn to reflect the main economic activities and household structures found in the larger study - as well as a spread of adults by age and gender.

Leading the sample choice was work status and occupation. Self-employment and wage work are conflated by some labour economists and in many work-related official statistics in such a way that the slums in question would be glossed as sites of poorlyemployed and under-employed workers - self-employed workers being theorized as 'disguised wage labour' (Banaji, 1977) and legislated for quite openly as wage labour (Sankaran, 2008). But there are sufficient theoretical and practical differences between the two forms of work to differentiate them as work status groups. While wage workers are exploited on labour markets, self-employed people may operate according to a logic of super-exploitation (in which they gain less per unit of time than wage workers) and in addition may be exploited on four (non-labour) markets - those for property, raw materials, money and finished products. Embodying both capital and labour, they expand by multiplication rather than accumulation (Harriss-White, 2009; 2012).

\footnotetext{
${ }^{28}$ For the purposes of this article the National Industrial Classification 1998 has been used to simplify industrial sectors into the three categories of trader, manufacturing and service.
} 
Forty-one 'business' individuals were chosen. These people saw themselves as selfemployed, as not working for others but for themselves and owning the means of production from which their predominant personal earnings were obtained. They included, for example, snack-makers and sellers, fish sellers, broom sellers, labour contractors, auto-drivers and cycle rickshaw pullers who owned or rented their vehicles. Eighty-two 'worker' individuals were chosen, self-identified as workers who labour for those who own the means of production. These included salaried, casual and piece rate workers in sectors such as domestic work, security guarding, construction work, lorry driving and call centre work. A few worked in the lower rungs of the formal economy, others were paid regular wages in the informal economy and yet others toiled on piece rates or for daily wages. The sub-sample choice also reflected the main occupations in the slums we studied, which in turn reflect both the age- and gender-segregated nature of work in Chennai and the site-specific and localised opportunities for work. The work status label was applied to the individual respondent, and was not measured using the occupations or assets of the rest of the household.

From the resulting 123 individuals, 91 had surveys that were complete over all three time-periods surveyed, comprising 17 business individuals and 74 worker individuals in 58 households. The adults and households had already been intensively studied by the field research team covering the large face-to-face household survey together with a year of qualitative research. ${ }^{29}$

\footnotetext{
${ }^{29}$ Recent events in international banking have highlighted the fallacy of the belief that written accounts are any more complete or accurate than verbal accounts; at essence most social research shares the method of taking the informant's word. With familiarity and trust, informants' willingness to participate rises and a comprehensive knowledge of the social context can be achieved through repeated visits to people's homes.
} 


\subsection{Slum Household Economy in Chennai}

While a household is a residential unit, a unit of reproduction and a unit of commensality, it may be provisioned - and its assets may be controlled - in many ways (Vera-Sanso, 1994, 1997). Individual household members may have their own separate assets and their individual (seasonal) portfolios of production, services; they may trade on their own account together with wage working for others. ${ }^{30}$ Even wage workers may possess workrelated assets and bear work-specific costs. A household's economy will then not be the pooled aggregate of the assets and net incomes of its economically active individuals which is how the concept of a household is generally understood by economists. There may indeed be a pooled set of assets and incomes but not all assets and income will be pooled. Some people's incomes (women's, particularly that of unmarried daughters) are more likely to be completely pooled than others. The only occupation that will be fed directly into the household economy is the housewife's efforts (paid or not) to meet immediate food consumption needs. So no household head - indeed no household member - necessarily knows the assets, debts and net incomes of all economically active household members. For this reason our research gathered detailed data on the household economy from the household head or spouse and from individual workers and selfemployed/business owners and did so without others present. It was possible to ascertain the veracity of the responses both by our knowledge of the families due to the recursive

\footnotetext{
We think the veracity of responses to our extensive questionnaires is as good, if not better, than surveys based on written records especially those gathered on a rapid single visit.

${ }^{30}$ Younger people tend to be in sectors and occupations that are more highly capitalised such as large scale construction and auto-driving, while older women tend towards street vending or services such as domestic help and older men towards services such as the night watch, cycle-rickshaw pulling and small scale piece-rate construction/building repair work.
} 
methodology of the larger study over the prior year of fieldwork and by comparison with other informants' responses. ${ }^{31}$

We examined the change in the economic circumstances of individual workers and selfemployed (reported by themselves) and of households (reported by their lead representatives) by asking for recall for the same period twelve months prior to each of three reference periods. . A range of economic and social attributes and experiences were collected both for households and for individuals (listed in detail in Olsen et al, 2010). And all respondents were asked to evaluate whether for each reference period their economic circumstances had gone up, down or stayed the same by comparison to the period twelve months earlier, on what they based their evaluation and to what cause they attributed any change. The last two were open questions to ensure that we included the summative indicator used by our respondents. Since the sample was not chosen at random we avoid using significance tests that assume randomness. All methods chosen for this analysis are appropriate to non-random small samples.

Slums are containers of marginalized people but the equations of slums with homogeneous sinks of poverty and/or of dominant processes of marginalization (whether as the 'reserve army' (Altvater, 1993) or the 'needs economy' (Sanyal, 2007)) deserve interrogation. Our research cannot avoid assessing the impact of shocks against the backcloth of existing differentiation in slum-households that are part of the global capitalist workforce. While the average household income within the slums (Rs $6300 / \$ 128$ per month) was similar across all sectors,(Table 1$)$. other dimensions of

\footnotetext{
${ }^{31}$ Detailed field methods are in Appendix 1.
} 
inequality involve inter-sectoral differences. Over the 2008-9 period, households where income was mainly derived from trading and retail had household assets that averaged 2.5 times greater in Rupee value than those in manufacturing sector. Eighty to ninety percent of assets were held in the form of property, including business-related assets, the remainder being small amounts of jewels, gold and consumer durables. 
Table 1: Averaged Levels of Assets and Income 2008-9 (Rupees) - Work Status and Industry Sector

\begin{tabular}{|l|l|l|l|}
\hline $\begin{array}{l}\text { 1. Work Status } \\
\text { Groups }\end{array}$ & $\begin{array}{l}\text { Household Income } \\
\text { (Rs/Month) }\end{array}$ & $\begin{array}{l}\text { Assets } \\
\text { (Rs.) }\end{array}$ & $\begin{array}{l}\text { Total Number of } \\
\text { Households }\end{array}$ \\
\hline Wage worker & 5,950 & $300 \mathrm{~K}$ & 49 \\
\hline Self-employed & 8,130 & $380 \mathrm{~K}$ & 9 \\
\hline
\end{tabular}

\begin{tabular}{|l|l|l|l|}
\hline 2. Industry Sector & $\begin{array}{l}\text { Household Income } \\
\text { (Rs/Month) }\end{array}$ & $\begin{array}{l}\text { Assets } \\
\text { (Rs.) }\end{array}$ & $\begin{array}{l}\text { Total Number of } \\
\text { Households }\end{array}$ \\
\hline Trading \& Retail & 6,130 & $519 \mathrm{~K}$ & 3 \\
\hline Manufacturing & 6,550 & $202 \mathrm{~K}$ & 15 \\
\hline Services & 6,200 & $236 \mathrm{~K}$ & 40 \\
\hline Overall & 6,290 & $301 \mathrm{~K}$ & 58 households \\
\hline
\end{tabular}

Nov 2008-May 2009 exchange rate $\$ 1$ = Rs 49 (average household incomes ranged from $\$ 121$ to $\$ 166$ per month and average assets ranged from $\$ 4,122$ to $\$ 10,591$ ). Assets included the value and number of 21 different consumer goods including mobile phones and bicycles, plus the value of rural and urban land and houses, as reported by one respondent on behalf of the whole household.

Table 2 shows assets inequality far exceeding income inequality. Across the slum household sample, the Gini coefficient of inequality of assets is 0.59 contrasted with 0.37 for monthly income. ${ }^{32}$ Within the sectors there is least asset inequality in trading and retailing, most in services; least income inequality in manufacturing, most in trading and retail.

Table 2: Inequality Measures for Slum Dwellers 2008-9

\begin{tabular}{|l|l|l|l|l|}
\hline & $\begin{array}{l}\text { GINI among } \\
\text { trading \& retail }\end{array}$ & $\begin{array}{l}\text { GINI among } \\
\text { manuf. }\end{array}$ & $\begin{array}{l}\text { GINI among } \\
\text { services }\end{array}$ & Overall GINI \\
\hline Total assets & .26 & .54 & .60 & .59 \\
\hline $\begin{array}{l}\text { Monthly income } \\
2008-9\end{array}$ & .41 & .29 & .39 & .37 \\
\hline
\end{tabular}

Inequality is not a matter of income alone it is also a matter of relationship to the means of production - or class. Slum residents work on their own account or on wages for others. However, as we argued earlier, self-employment is a different category, not

${ }^{32}$ Monthly income includes that from state pensions and transfers. 
insofar as assets are required for it - for many wage workers are forced to own a hod, a head-loading basket, a pickaxe or a hoe and, increasingly, in urban areas a mobile phone in order to secure casual work and to manage workloads across a number of employers, as happens for domestic workers, office cleaners and construction workers. Rather the difference lies in self-employment's embodiment of both capital and labour in a single minute enterprise - operating according to the distinctive logic of self-exploitation (Harris-White, 2010). ${ }^{33}$ However, in being vulnerable to self-exploitation the selfemployed may also be more resilient than wage-workers to shocks such as those which occurred in 2008-9. Table 1 reveals that income is not evenly distributed between the two work status groups. While average household assets were $25 \%$ higher for households where the head of household was self-employed than for those with the household head in wage work, average monthly income (which was quite similar across the sectors of the economy) was $33 \%$ higher for self-employed people.

Slum households are often characterized as having multiple and diverse sources of income and this is particularly so in contexts where formal sector employment has been comparatively widely available, as in Latin America (e.g. de la Rocha, 2007); however, in a country such as India where at least $86 \%$ of people work in the informal economy (NCEUS, 2009) and where occupation is still strongly stratified by caste, religion and regional origin as well as gender and age (Harriss-White, 2003) diverse livelihood combinations were not common and tended to be found only in the very largest

\footnotetext{
${ }^{33}$ Harriss-White, 2010
} 
households. $^{34}$ It was therefore not possible to test for the impact of diversity in livelihoods on the change in economic circumstances - or vice versa.

Savings can represent a cushion against the costs of shocks. Figure 1 summarises information about household savings, debt and income The savings that were covered in our survey were provident funds (usually linked to life insurance), chit funds (i.e. rotating informal savings, of which only some are formalised under the law for cooperative banks), bank savings, post office savings funds, sangams i.e. unions such as a farmer's union or women's group. Jewellery was not considered under the heading savings. The quantities saved varied but averaged Rs. 3600 (\$73), comparing adversely with average debts of Rs. 15,000 (\$306) per household. Table 3 not only shows the exiguity of savings in relation to debt, it shows that in all industry sectors a minority of households which saved continued to save during the period of economic and environmental shocks. Locked into a pattern of monthly cash saving intended to cope with shocks like sickness or death or to redeem pawned valuables, families reduce food consumption in order to protect existing savings in chit funds and Self Help Groups. Yet the overall picture of poverty remains: $74 \%$ households had no savings at all.

By contrast, in trading households, which had the highest average level of assets, debts to various sources equal the amount of annual income. The stock of debts is double the annual income in manufacturing households and three times as high as income in the households in services. Formal credit is available to many households in informal

\footnotetext{
${ }^{34}$ Where households had more than one income the income of the household head was taken to define the household's class and industry sector.
} 
settlements through housing loans, but informal credit is also widely available either as a complement or substitute for formal credit. Credit included informal loans, bank loans, chit fund loan and self-help group loan. Thus the savings recorded here tended toward formal savings vehicles while the credit included both formal and informal loans.

State transfers, such as the targeted social pension, are an exceedingly small component of income. All pensions were Rs 400/m (\$8/m). In the 9\% of households that included people receiving pensions, the household income ranged from a monthly average income of Rs 700/month (\$14), for a single person household, through a monthly average of Rs 24,000 (\$490) for the richest single household. But of the 25 poorest households (getting under Rs 5000/\$102 per month) 11 , or $44 \%$ - or nearly half - received no state cash transfers. This confirms the results of qualitative research undertaken as part of the larger mixed methods research project which found that numerically capped and targeted pensions tend to exclude the poorest eligible people. They cannot afford the bribes, the payments to agents or the time off work to pursue a pension application (Vera-Sanso, 2010). 


\section{Figure 1: Household Income and Debt by Industry Sector}

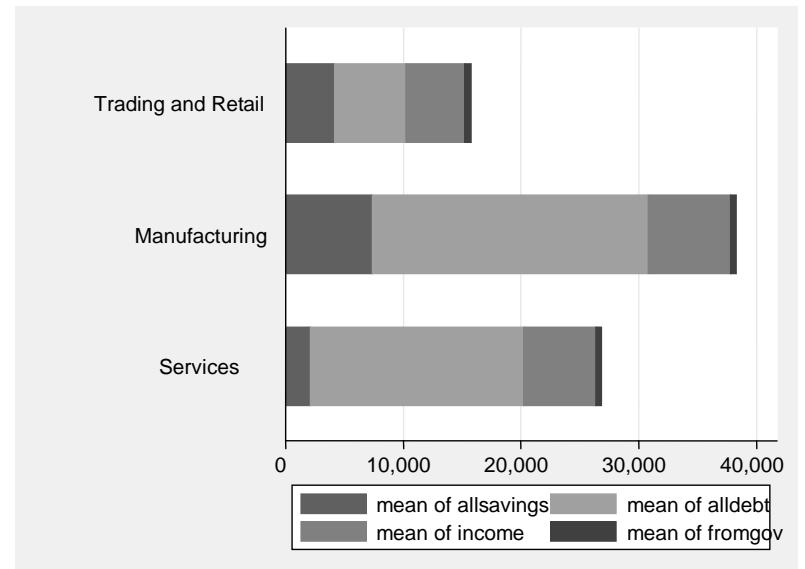

Key: All figures are household averages. From left to right, the figure shows all savings in six types of medium (bank, provident fund, chit fund, etc.), all debts, monthly income, and state cash transfers. Debt and savings were reported once for the entire household (in each time period), not for each individual 
Table 3: Household Savings and Debt*

\begin{tabular}{|l|l|l|l|l|l|}
\hline $\begin{array}{l}\text { 1. Work status } \\
\text { groups }\end{array}$ & $\begin{array}{l}\text { Mean } \\
\text { Bank } \\
\text { Savings }\end{array}$ & $\begin{array}{l}\text { Mean Total } \\
\text { Savings** }\end{array}$ & $\begin{array}{l}\text { Mean } \\
\text { debt } \\
\text { (Rs.) }\end{array}$ & $\begin{array}{l}\text { \% with rising } \\
\text { overall } \\
\text { savings } \\
\text { (periods 1-3) }\end{array}$ & $\begin{array}{l}\text { Total Number } \\
\text { of Households }\end{array}$ \\
\hline Wage workers & Rs. 461 & Rs. 4392 & 15,832 & $27 \%$ & 48 \\
\hline Self employed & Rs. 167 & Rs. 1797 & 32,383 & $10 \%$ & 10 \\
\hline $\begin{array}{l}\text { 2. Industry } \\
\text { Sector }\end{array}$ & $\begin{array}{l}\text { Mean } \\
\text { Bank }\end{array}$ & $\begin{array}{l}\text { Mean Total } \\
\text { Savings* }\end{array}$ & $\begin{array}{l}\text { Mean } \\
\text { debt } \\
\text { (Rs.) }\end{array}$ & $\begin{array}{l}\text { \% with rising } \\
\text { overall } \\
\text { savings } \\
\text { (periods 1-3) }\end{array}$ & $\begin{array}{l}\text { Total Number } \\
\text { of Households }\end{array}$ \\
\hline Trade and retail & Nil & Rs. 4133 & 6,066 & $20 \%$ & 5 \\
\hline Manufacturing & Rs. 963 & Rs. 7369 & 23,427 & $33 \%$ & 18 \\
\hline Services & Rs. 186 & Rs. 2145 & 18,051 & $20 \%$ & 35 \\
\hline $\begin{array}{l}\text { Overall } \\
\text { Average }\end{array}$ & Rs. 411 & Rs. 3937 & 18,686 & $24 \%$ & 58 \\
\hline
\end{tabular}

NOTE: N=58. The debt and savings had been reported and summed across the whole household over three periods. These are then averaged across households in each group. * 43 households out of 58 have no savings at all. **Total savings include those in banks, post offices, provident funds, sangam and self-help groups, chit funds, and government funds. Mean total savings ranged from under $\$ 37$ to $\$ 150$ and mean debt ranged from $\$ 323$ to $\$ 660$.

With 43 households out of 58 having no savings whatsoever and debts substantially outweighing savings, especially in the service sector - which includes auto-drivers and others who are buying their work assets on hire purchase - vulnerability to economic and climatic shocks is acute. The rising savings that were recorded by some households between periods 1 and 3 present an interesting analytical conundrum; they can result from improving economic circumstances or they can trigger further deprivations in other areas of wellbeing (nutrition/education/health care) as families try to protect the type of assets in formal and informal saving systems (chit funds especially) that lock families into ongoing savings. 


\subsection{Mobility in Economic Circumstances: Fuzzy Variables and Logic}

Under conditions of complexity and when data vary both in their precision or their mode of assessment or measurement, it is difficult to make precise statements about behaviour. The comparison of self-assessed 'economic circumstance' across three sets of point to point comparisons is an evident example of complexity. Fuzzy variables are concepts that simplify complexity in precisely specified 'if-then' ways. If numerical values can be assigned with reasons to a complex set of measured and intuitive conditions, they unblock the road to further analysis. A fuzzy variable was constructed from the combinations of upwards and downwards trajectories in the self-reported economic circumstances of the 91 wage workers and self-employed respondents. Another fuzzy variable reflected the self-reported upward or downward trajectories of the 58 household economies:

0 if an individual or household's economic circumstances went 'down' in 3 periods,

.17 if they went 'down' in 2 periods and were neutral

.33 if they went 'down' in 1 period

.50 if they were neutral

.67 if circumstances went up in 1 period, and were neutral or down in the other periods (i.e. if 1 'up' was mentioned at all).

.83 if they improved in 2 periods, and were neutral or down in a third period (i.e. if 2 'ups' were mentioned at all). 
1.00 if in all three periods they reported their economic circumstances as having gone 'up' .35

Summaries of the movement of the household economic circumstances by household head's age and by the age of individual workers are presented in Figures 2 and 3. Table 4 presents summary measures of the outcomes for both 'economic circumstances' and incomes. These constitute the dependent variables in the later qualitative comparative analysis - in section 4 below.

Powerful answers to the principal research question emerge. First, from an analysis of the 91 workers surveyed in-depth, there is clearly much deterioration in economic circumstances during $2008-9$. The majority ( $82 \%$ of wage working individuals and $72 \%$ of those who were self-employed) experienced no improvement in economic circumstances while a subset of over $20 \%$ went continually downwards. While a fifth of individuals had episodes of improvement in otherwise downward or stagnant trajectories, only four out of 91 individuals $(4.3 \%)$ considered that their economic circumstances had improved throughout the three periods in 2008-9 over those a year earlier. The trend for households (as opposed to individuals) was even more unambiguously downwards. A third had absolute declines in household incomes from November to March, the median being Rs 500 and the most severe drop exceeding Rs $5000 .{ }^{36}$ Forty per cent of households faced absolute decline in incomes from March to May 2009, the median being about the same as the first period while the most extreme crash exceeded Rs 10,000 (\$204). All

\footnotetext{
${ }^{35}$ This is denoted by a single variable when aggregated over the whole of the three periods as shown in Figures 2-3 and Appendix 1. Figure 2 shows the results for informants' assessment of their households' economic circumstances, and Figure 3 gives the individuals' assessment with regard to their individual experiences as wage or self-employed worker.

${ }^{36}$ I.e. $\$ 10$ and $\$ 102$ - significant in households with monthly incomes ranging from $\$ 121-\$ 166$.
} 
households experienced their economic circumstances as going down during 2008-9 itself except two of the three Trading and Retailing households who considered their circumstances had gone up in the final period after two downward phases that had forced the pawning of jewelry and the taking on of work as housemaids.

Second, irrespective of the age of the household head, the economic circumstances of the overwhelming majority of households deteriorated or stagnated throughout the reference period, In a few households with household heads under 45 or over 60 years the period of November 2007-May 2009, was reported as one of no change or some improvement. However, for households with heads in the 46 to 59 age range with high dependentworker ratios and incomes from wage work in services, economic circumstances deteriorated consistently. ${ }^{37}$ Third, the older the individual respondent the less likely s/he is to have reported any upward change in economic circumstance during the period. Not only do respondents over 60 earn a third less than younger people but of the 30 out of 91 individual respondents whose age exceeds 60 years only 3 reported anything but deterioration in all of the 3 periods. ${ }^{38}$

\footnotetext{
${ }^{37}$ In slum households low consumer-worker ratios in this age band is most frequently a response to particularly low or insecure incomes.

${ }^{38}$ The average monthly incomes for individual respondents aged under 60 was Rs7,708 (\$157) and Rs5,611 (\$114) for individuals over 60.
} 
Figure 2: Change in Economic Circumstances of Households by Age

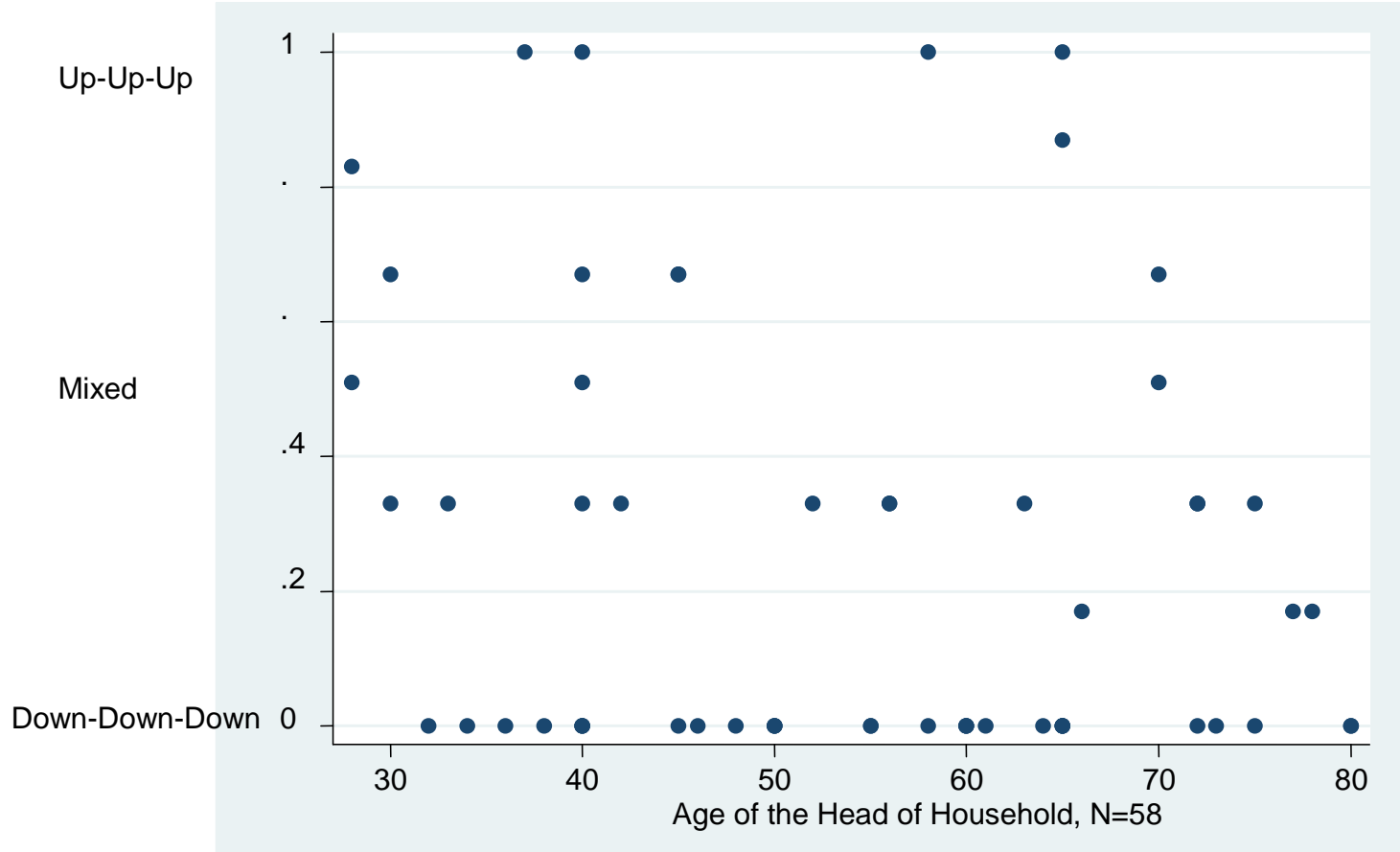

NOTE: $\quad \mathrm{N}=58$ The vertical axis is the fuzzy intersection of whether the household's economic circumstances were thought to have improved or deteriorated in the three 12-month periods ending November 2008, January 2009 and May 2009. 


\section{Figure 3: Change in Economic Circumstances of Individuals by Age}

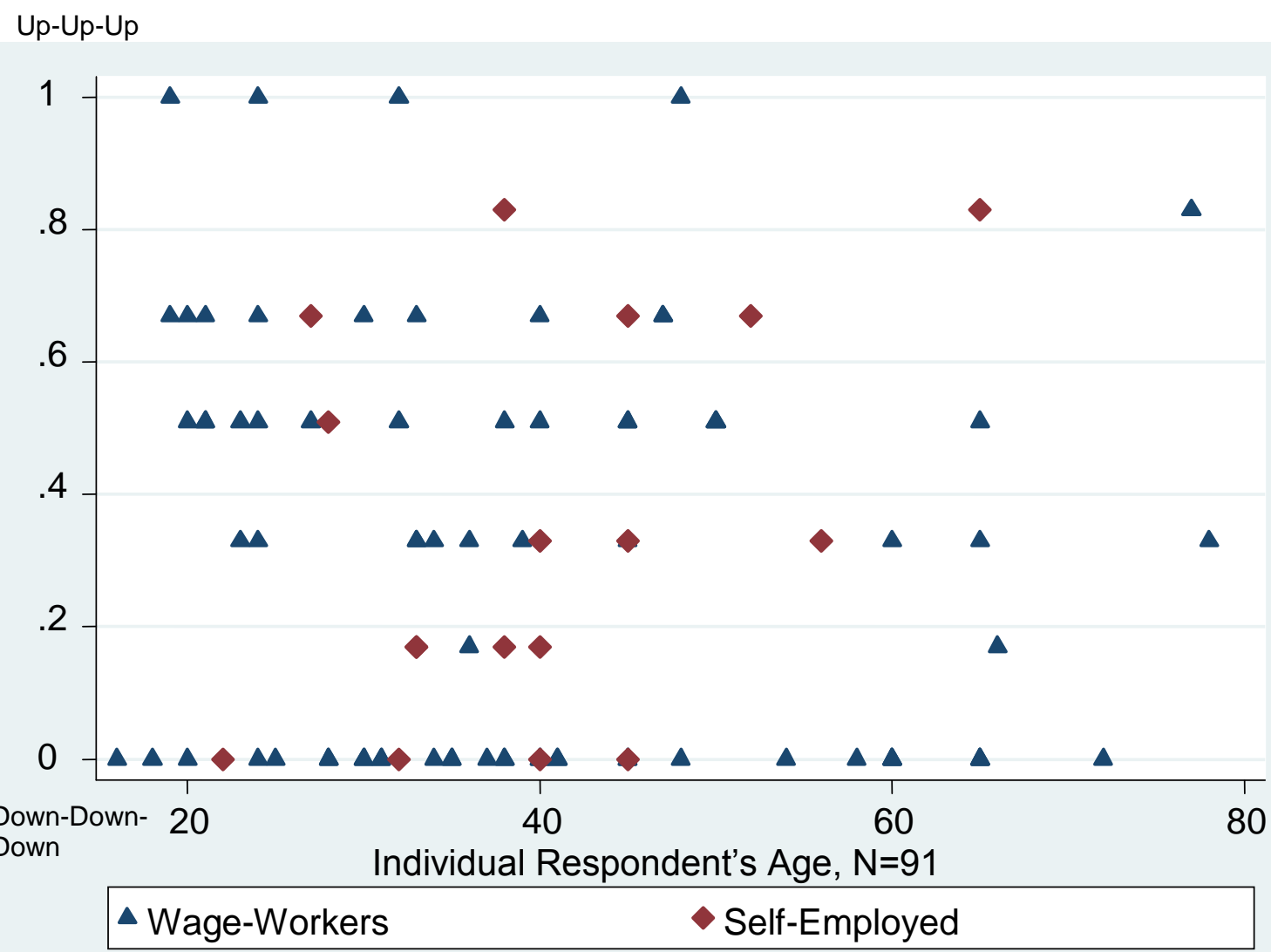

NOTE: $N=91$. The figure shows the individual respondent's work status with self-employed as triangles and wage workers as diamonds, against their age on the $\mathrm{x}$-axis, and whether their economic circumstances improved at all on the vertical axis. The vertical axis is the fuzzy intersection of whether their personal economic circumstances were thought to have improved or deteriorated in the three 12-month periods ending November 2008, January 2009 and May 2009. 
Table 4: Changing Economic Circumstances in 2008-9 in Slums of Chennai (Rs.),

\begin{tabular}{|c|c|c|c|c|}
\hline $\begin{array}{l}\text { 1. Work status } \\
\text { groups }\end{array}$ & $\begin{array}{l}\text { Average } \\
\text { Change in } \\
\text { Monthly } \\
\text { Income } \\
\text { Period } 1 \text { to } 2\end{array}$ & $\begin{array}{l}\text { Average } \\
\text { Change in } \\
\text { Monthly } \\
\text { Income } \\
\text { Period } 2 \text { to } 3\end{array}$ & $\begin{array}{l}\text { Overall } \\
\text { Movement of } \\
\text { Econ. Circs* } \\
\text { 0=DOWN. } \\
\mathbf{1 = U P .}\end{array}$ & $\begin{array}{l}\text { Movement of } \\
\text { Econ. Circs in } \\
\text { Periods } 1,2 \text {, } \\
\text { and } 3 * * \\
\mathbf{0 = D O W N .} \\
\mathbf{1 = U P .}\end{array}$ \\
\hline Wage worker & +192 & +147 & .24 & $.22, .26, .28$ \\
\hline Self-employed & +386 & $-1,105$ & .34 & $.17, .23, .45$ \\
\hline
\end{tabular}

\begin{tabular}{|l|l|l|l|l|}
\hline $\begin{array}{l}\text { 2. Industry } \\
\text { Sector }\end{array}$ & $\begin{array}{l}\text { Average } \\
\text { Change in } \\
\text { Monthly } \\
\text { Income } \\
\text { Period 1 to 2 }\end{array}$ & $\begin{array}{l}\text { Average } \\
\text { Change in } \\
\text { Monthly } \\
\text { Income } \\
\text { Period 2 to 3 }\end{array}$ & $\begin{array}{l}\text { Overall } \\
\text { Movement of } \\
\text { Econ. Circs* }\end{array}$ & $\begin{array}{l}\text { Movement of } \\
\text { Econ. Circs in } \\
\text { Periods 1, 2, } \\
\text { and 3** } \\
\mathbf{1 = U P .}\end{array}$ \\
\hline $\begin{array}{l}\text { Trading \& } \\
\text { Retail }\end{array}$ & -333 & $+1,350$ & $\begin{array}{l}.53 \\
\mathbf{1 = U P .}\end{array}$ & $.17, .17, .84$ \\
\hline Manufacturing & +83 & +783 & .35 & $.30, .30, .37$ \\
\hline Services & +262 & -171 & .19 & $.18, .24, .24$ \\
\hline Overall & +185 & +155 & .25 & $.20, .25, .30$ \\
\hline
\end{tabular}

NOTE $\mathbf{N}=58$. $*$ The subjective question about changing economic circumstances is described in detail earlier. ${ }^{* *}$ The use of a fuzzy set for each period gives a simple coding which is averaged out here using the group mean. The set membership scores are $0=$ went down. $0.51-$ neither went down nor up. $1.0=$ went up.

There are differences between trajectories tracked on the one hand using fuzzy variables of perceived economic circumstances and several background factors, including dimensions un-measurable by money, and on the other hand using outcomes reported as monthly income. Table 4's two right hand columns showing fuzzy variables reveal that for households where the household head was self-employed, there was general downward movement compared to the preceding year in periods 1 and 2, while some recovery was reported for period 3. The service sector persists in recording deterioration throughout the survey rounds. Wage worker households have less dispersed values for economic circumstances, declining less dramatically than did the self-employed households in the early phase and recovering less dramatically in the later one. Such 
trajectories reflect the impact of three trading and retail households on the total sample of nine self-employed.

By contrast average reported monthly incomes (in the two left hand columns) rose slightly throughout the period with three exceptions: i) households with a self-employed household head - which plunged significantly in the period March to May 2009 after a small rise in the November 2008 to March 2009; ii) households whose household head worked in services - where some plunged later, from March to May 2009 (the services average is affected by a few outliers with extreme negative trajectories) and iii) households whose household head worked in trading and retail (where they nose-dived between November 2008 and March 2009 and one out of three did not recover in the later period).

The two methods of experiencing and of analyzing this period of shocks can be reconciled because the perception of economic circumstances includes the aggregate effect of incomes, expenditures under conditions of rapid inflation of basic wage-goods prices, assets, shifting intensities and duration of work, enforced up-take of paid work by carers and others and changes in work security. But the absolute averages are confined to incomes and exclude the effect of the full range of factors by which people assess their economic circumstances. When asked to provide the main reason for their household's changed economic circumstance $50 \%$ of respondents cited price rises, $20 \%$ cited insufficient work and the remainder of those who considered their family to have 'gone down' during the period cited illness (raising costs/lowering income) and shifts in family 
make up (including married sons leaving because of overcrowding or married sons no longer being able to support older parents). Informants describing changes in the income/expenditure balance that lies at the core of their economic circumstances spoke of their deteriorating debt status, reduced food consumption and compromised capacity to replace broken and worn out things. Twenty percent said their main measure of 'going down' was going into debt and pawning their assets, $15 \%$ cited significantly reduced income and $20 \%$ cited lower quality and less food intake - in a state in which over $50 \%$ of women had anaemia prior to the series of economic shocks discussed here (Govt of Tamil Nadu, 2003).

So the aim of the final part of the analysis presented here is to explore detail to discover whether and if so why there may be differences in the patterns of deterioration in economic circumstances during 2008-9 among the people and households represented in these diagrams.

\section{Detailed Data Analysis and Methods: Qualitative Comparative Analysis (QCA)}

The qualitative comparative analysis (QCA) method formalizes the logic of qualitative analysis. It is appropriate for problems in which the researcher assumes an ontology where factors operating at different 'levels', 'scales' or 'dimensions' (such as region, occupation, household, sector, and individual) work in tandem to cause outcomes that emerge at the various levels. Clearly a prior qualitative (and partly theoretical) step is needed to develop views about what may be causing the outcome, and how sensibly to delineate that outcome. Our in-depth field research provides confidence in reasons for 
claiming that causes $\mathrm{A}, \mathrm{B}$ and $\mathrm{C}$ may be sufficient for an outcome $\mathrm{Y} .{ }^{39}$ In each main age group there are men and women, workers and self-employed, old and young with roughly equal parts of the sample. Data are being used here as relatively simple proxies for complex aspects of economic and demographic realities in slums.

In qualitative comparative analysis, Boolean logic is used to reduce a simplified fuzzy 'truth table ${ }^{40}$ to get a more parsimonious summary of the configurations associated with the outcome (Ragin, 2008a). We tested hypotheses about the impact pathways theorized from the economic and environmental shocks reviewed earlier. That is, we hypothesized that being female, being 60 or over, being a wage worker and being a member of a household with a high dependent-worker ratio would threaten economic circumstances. The service sector was hypothesized as being more robust than manufacturing or trade, as were relatively stable salaries on monthly contract and transfers or pensions from the state. For a given level of income, multiple and diverse sources of income will protect a household more than a single source (and their incomes will be likely to aggregate to a higher total).

There are data to test the following variates for individuals and their economic circumstances in 2008-9: being female, being older (fuzzified age), being a worker (versus self-employed), having a household of higher than average age, being in the

${ }^{39}$ In the case where $\mathrm{A}$ (but not $\mathrm{B}$ and $\mathrm{C}$ ) are present, the outcome might not occur, because A may require a conjuncture with $\mathrm{B}$ and / or $\mathrm{C}$ to cause $\mathrm{Y}$. To test for conjunctural causality, every permutation of the $\mathrm{A}$ B C Y set may need to be tested. Our results focus on sufficient causality and these results are based on sets of cases where we have contrasts on both the independent variables and the outcomes.

${ }^{40}$ A 'truth table' refers to a table with information regarding the different combinations of conditions that may or may not have produced a specific outcome. See Ragin (2008a). 
trading and retail sector, being in the service sector, having a salary that is regular (but with a few exceptions, notably railway salaries and pensions, the sampled salaries are informal sector salaries); having a high level of state transfers and / or pension in the income portfolio in 2008-9, together with the dependent-worker ratio of the household. Household level variates tested for households' being associated with rising economic circumstances in 2008-9 include: a household that has a wage worker, average household age, household size, the household head's engagement in trading and retail, manufacturing or services ; the total value of all mobile and immobile property including jewelry and 21 other assets; income from government subsidy; whether the household was putting regular savings into liquid or illiquid destinations on a rising basis over 2008-9; whether the household had been made to pay bribes in the last year; the dependent-worker ratio of the household, and last but not least whether the head of the household is self-employed or a wage worker.

The fuzzy set for several variables split the sample into six equal parts. Age of household head, average household age, household size, income, total property value were each put onto this scale with values $00.170 .33,0.51$ (to avoid the ambiguity of 0.50 ), 0.670 .83 and 1.0 to correspond with the fuzzy set membership values for outcomes. ${ }^{41}$ First, these data were examined using regression methods, with logged income and assets, but, with small sample sizes, no strong results emerged. Some variables were expressed as binaries (the household containing a widow/er, the household head being a widow/er or deserted;

\footnotetext{
${ }^{41}$ In making a fuzzy set, two calibration decisions were made here. Firstly it was useful to have seven boundaries for these sets since there were seven natural boundaries for the DOWN fuzzy set. It was considered desirable to split up the variables' histograms approximately into six equal parts for these fuzzy sets. We have set the neutral middle values to 0.51.for technical reasons (Ragin, 2008b; see also Rihoux and Ragin, 2009; Rihoux and Grimm, 2006.)
} 
the gender of respondent; forced bribery; and self-employment vs. wage-work status as two fractions within the slum working class).

\section{Results of QCA Models}

Much stronger results were obtained with QCA than could be obtained by examining individual cases. First, results for individuals could be differentiated from the economic circumstances of the households. Second, although slum dwellers' experiences were diverse, QCA has the capacity to pick up patterns which the human eye and intellect would struggle to discern unaided. ${ }^{42}$

Table 5: Two Configurations Causing Declining Individual Economic Circumstances, Slum Dwellers of Chennai, 2008-9

\begin{tabular}{|l|l|l|}
\hline Configuration X & $\begin{array}{l}\text { Coverage (\% of Cases } \\
\text { which are Covered by This } \\
\text { Configuration X)* }\end{array}$ & $\begin{array}{l}\text { Consistency for Sufficient } \\
\text { Causality } \\
\text { (depending upon the } \\
\text { Boolean combination of Y } \\
\text { and X) }\end{array}$ \\
\hline $\begin{array}{l}\text { X1 Household has a wage } \\
\text { worker }\end{array}$ & $32 \%$ & .84 \\
\hline $\begin{array}{l}\text { X2 Respondent is male and } \\
\text { the dependent-worker ratio } \\
\text { is high }\end{array}$ & $\begin{array}{l}44 \% \text { (of which 16\% are in } \\
\text { the Salaried configuration } \\
\text { too) }\end{array}$ & .88 \\
\hline $\begin{array}{l}\text { Overall with these two } \\
\text { configurations }\end{array}$ & $60 \%$ & .86 \\
\hline
\end{tabular}

*Note that in the fuzzy Boolean algebra the meaning of coverage varies slightly from its usage in crisp set analysis / QCA. However its scaling from 0 to 1 and its meaningfulness as an indicator of a configuration's relative size to the whole set of configurations is common to both crisp and fuzzy modes of measurement. The unique coverage is in column 2.

The first row of Table 5 shows that individuals doing wage work were badly affected with a three-period decline in 2008-9. The second row reveals that a larger group comprising men in households with a high dependent-worker ratio were also badly

\footnotetext{
${ }^{42}$ A point confirmed by Ragin, 2008b.
} 
affected. Households relying on one male income were much less able to weather the effects of sudden contraction in the economy, price rises and climatic shocks.

The model for households indicates clearly that having a household head who is i) a wage worker and ii) in the service sector (e.g. security guard, sweeper, or maid) is sufficient to cause a three period decline in economic circumstances. Table 6 summarises the information. Either of the configurations shown is sufficient to cause deterioration in $71 \%$ of cases. The first row shows that the large group of individuals whose head of household was a wage worker in services had a three period decline in 2008-9. The second row identifies a very small group comprising relatively young households (not necessarily small ones) where the respondent was self-employed in sectors other than services. This group was also badly affected.

\section{Table 6: Two Configurations Causing Deteriorating Household Economic Circumstances, Slum Dwellers of Chennai, 2008-9}

\begin{tabular}{|l|l|l|}
\hline Configuration & $\begin{array}{l}\text { Coverage (The degree to } \\
\text { which the cases are covered } \\
\text { by each configuration X)* }\end{array}$ & $\begin{array}{l}\text { Consistency for Sufficient } \\
\text { Causality } \\
\text { (The degree to which the } \\
\text { cases conform to the } \\
\text { sufficient-cause pattern) }\end{array}$ \\
\hline $\begin{array}{l}\text { X1 Respondent is in } \\
\text { services and respondent is a } \\
\text { wage worker (not self- } \\
\text { employed) }\end{array}$ & $67 \%$ & .82 \\
\hline $\begin{array}{l}\text { X2 Household head is not } \\
\text { in the service sector, but is } \\
\text { self-employed and the } \\
\text { household has a low } \\
\text { average age }\end{array}$ & $4 \%$ & .92 \\
\hline $\begin{array}{l}\text { Overall with these two } \\
\text { configurations }\end{array}$ & $71 \%$ & .83 \\
\hline
\end{tabular}


*Note that in the fuzzy Boolean algebra the meaning of coverage varies slightly from its usage in crisp set QCA; see Ragin (2008). The unique coverage is shown here.

\section{Conclusions}

We have examined the impact of a series of economic and environmental shocks from November 2008 to May 2009 on the economic circumstances of individuals and households living in five Chennai slums in Tamil Nadu. While economists still tend to examine welfare outcomes through income, the concept of income ignores vital components of the household economy such as the income-expenditure relation, the dynamics of assets and distress-induced increases in the dependent-worker ratio. ${ }^{43}$ By contrast, the idea of 'economic circumstances' was well understood by slum dwellers to involve the capacity to balance income and expenditure, to reconcile combinations of assets and liabilities (including loans), and to control expenditure and other outlays (in conditions when (forced) savings may even be conceived as an outlay). Our research uses both etic and emic concepts (income and economic circumstances respectively) to trace outcomes.

At the outset, these households were expected to be challenged by the local effects of the national slow-down in growth that were in turn predicted to be due to multiplier effects on India's real economy of the global financial crisis of late 2008. During the real-time of the research these households also had to confront resurgent price inflation in basic wage

\footnotetext{
${ }^{43}$ The analysis of expenditure is a future project.
} 
goods such as food and fuel, together with intense heat-waves, cyclones and floods. So the research was framed to investigate shocks as a concatenation phenomenon.

We found no existing theory to guide this research so developed hypotheses of our own. Since the quantitative data were unsuitable for standard analysis using regression, we also applied novel methods involving fuzzy variables and Qualitative Comparative Analysis (QCA). This is the first such application to slum research.

Our data show that informants - lead respondents of slum-dwelling households - were more resilient at the beginning than later but were unable to sustain that resilience over the whole period as growth in the wider economy deteriorated, as inflation eroded real incomes ${ }^{44}$ and environmental impacts hit (notably the May heat).

\subsection{Substantive Conclusions}

Our analysis had three stages. First, to make the complexity that we encountered tractable, we classified occupations - almost all of which were in the informal economy in terms of the three broad industry sectors in which the household head works: the service sector; trade and retail; and manufacturing. We further disaggregated households in terms of the work status distinction between the household head's self-employment in informal business (such as petty trading) or as a wage worker (including casual labour).

Our descriptive research revealed structures of diversity and complexity within slums. Workers were spread across a spectrum of assets, debt status, household sizes together

\footnotetext{
${ }^{44}$ See Appendix 4, in Olsen et al, 2010 for details.
} 
with the average age of the household. They were differentiated in differentiated ways as has also been observed for rural Tamil Nadu (Colatei and Harriss-White, 2004) Assets inequality exceeded income inequality and while these assets may have also involved debt (instalment purchase, housing loans and stock on credit) the capacity to secure credit is a measure of comparative advantage. Eighty percent of households had no assets whatsoever and $74 \%$ no savings. Incomes of self-employed households exceeded those of wage workers by a third. Older workers' incomes were lower than younger people by nearly a third. And small households tended to be poorest.

Second, we analysed economic trajectories during the period of environmental and economic shocks. For these we used monthly incomes together with a fuzzy variable for economic circumstances at three points in time from November 2008 to May 2009 that made a point-to-point comparison with the period 12 months earlier in order to iron out regular seasonal variation. The results are clear but nuanced. We find a difference between trajectories traced through income and those from perceived / experienced economic circumstance. There were further differences according to economic sector / industry group and also in the two work status groups. In $80 \%$ of individual cases economic circumstances deteriorated or stagnated. Incomes in self-employment and in trade and retail nosedived in the early phase, then rallied. Economic circumstances in self-employment plunged early but by May there had been some recovery. Self-employed retailers did better than wage workers, probably due to their capacity to work until they had secured the income they needed - while wage workers did not have that option. The latter said their wages stagnated in absolute terms but declined in real terms as 
competition for work in the labour market rose. In the service sector economic circumstances declined in the early phases and tended to stagnate later on. Age mattered. Of the third of individuals who were over 60 , only $10 \%$ (i.e. $3 \%$ of the individuals sampled) reported anything but decline in the three periods.

Third, Qualitative Comparative Analysis (QCA) revealed the different characteristics of individual from household experiences during 2008-9 and confirmed the important finding that individuals (both men and women) aged 60 and over suffered more than those below 60 .

Just as we theorized in the third and fourth impact pathways at the start of this paper, we find that respondents doing wage work whose households had higher than average dependent-to-worker ratios were most injuriously hit by the shocks. .

Among the 58 households studied, the rarer upward changes in economic circumstance towards mid 2009 were associated more closely with the economic characteristics of the household than with demographic features such as their age composition. This strongly confirmed the vulnerability of wage work in the service sector to deterioration during the period of shocks, and this was especially so for people aged 46-59 who were additionally hit by age discrimination in the context of increased competition for work. A small group of young households, self-employed in other sectors (manufacturing and trade and retail), also deteriorated badly. However in general the reverse is true and households which had a self-employed respondent and those depending on trade and retail were better protected 
against economic and environmental shocks than those in manufacturing and services especially wage workers.

\subsection{Policy Conclusions}

Policy conclusions to both exploratory and hypothetico-deductive research are usually residual and made in ignorance of the politics of policy and the common technologies of power operating within policy processes (Fernandez, 2008). A quarter century ago in public administration research this tendency to residualise policy implications and conclusions was criticized as being irresponsible, on the grounds that residual policysuggestions create plenty of escape hatches for the researcher and policy maker alike (Schaffer, 1984). Meanwhile evidence-based policy continues to be rejected in favour of policy-based evidence. Given this epistemological quagmire, here we examine aspects of the state welfare system that would need to be solidly in place before other policies for slum dwellers have any chance of being implemented in ways they appear to be intended.

The physical fabric of slums is by definition a series of sinks of infrastructural neglect, on top of which slum-dwellers are vulnerable to many shocks - including the environmental and economic ones discussed here. While India's national financial arrangements turned out to be relatively well protected from the crisis for what mainstream economists in the

Planning Commission argued were the wrong reasons (their global integration was insufficiently rapidly advanced), the global financial crisis hit the real economy and rippled through the slums, compounding the effects of cyclones and heat-waves. Wage work (which $84 \%$ of sample households were providing) proved more vulnerable than 
self-employment; services (which $69 \%$ of sample slum households engaged in) proved more vulnerable than manufacturing or trade. Yet Tamil Nadu's economic agenda provides little effective protection for people at work, particularly in wage work - outside state work-fare in rural areas (e.g. the NREGA, Reddy and Upendranath, 2009). More effective protection at work could include the enforcement of Minimum Wages, three elements of the ILO's Decent Work agenda ${ }^{45}$ (rights to work, at work, and to organization and 'dialogue') and even the extension of the Employment Guarantee to slums to improve their physical infrastructure.

However Tamil nationalist political parties have for decades been locked in competition developing a wide-ranging project protecting people outside work. Its scope extends not only (often hardly at all) through the health and education system but more distinctively through noon meals, subsidized essential commodities and the beginnings of a BPL welfare state, including some targeted pensions. Lately (aided by revenues from alcohol) the state has even started to subsidise consumer durables - newly conceived as 'basic' needs - such as TVs and cooking-stoves. Tamil people have referred to this project as 'our socialism'. But although their objective is to help stabilize income, state transfers are currently a minute component of slum income. If these transfers were no longer rationed among poor households, they would relieve the distress of most vulnerable people. Our research shows that the de-rationing of pensions would be particularly effective in this respect. Measures to stabilize the prices of basic wage goods would also protect slum households from what we have shown are punitive economic and environmental shocks. Apart from the consumer durables, none of this is other than the project of promotive,

${ }^{45}$ http://www.decentwork.org/ 
preventive and protective social security already developed in the 1990s by the late S. Guhan (2003). And rights to social security, the fourth strand of the ILO's Decent Work agenda, has been long championed by the National Commission for Enterprises in the Unorganised Sector. ${ }^{46}$

In these Chennai slums, however, all these projects have a long way to go.

${ }^{46}$ http://nceus.gov.in/Report_Bill_July_2007_index.htm 


\section{References}

Ackerman F. 2008 The economics of collapsing markets Real-world Economics Review, 48, pp 279-290

ADB (Asian Development Bank) 2009 The Global Economic Crisis: Challenges for Developing Asia and $A D B$ 's Response ADB, Manilla

Alagh Y. 2008 India and the world, Plenary presentation to the conference 'Development, Freedom, Welfare' Cornell University and Institute of Human Development, New Delhi, December 2008

Anand N. (2006) Disconnecting Experience: making world-class roads in Mumbai', Breslauer Symposium: The Right to the City and the Politics of Space, UC Berkeley, April 142006.

Anjaria J. (2006) Street Hawkers and Public Space in Mumbai, Economic and Political Weekly May 27.

Banaji, J. 1977. "Modes of Production in a Materialist Conception of History", Capital And Class, 1:3, pgs $1-44$.

Bhan, G. 2009. 'This is no longer the city I once knew'. Evictions, the Urban Poor and the Right to the City in Millennial Delhi. Environment and Urbanisation, 21:1 127-42

Bouchaud J.P. 2008 Economics needs a scientific revolution, Real-world Economics Review, 48, pp 291292

Chandramouli, Dr.C., I.A.S. "Slums In Chennai: A Profile" in Martin J. Bunch, V. Madha Suresh and T. Vasantha Kumaran, eds., Proceedings of the Third International Conference on Environment and Health, Chennai, India, 15-17 December, 2003. Chennai: Department of Geography, University of Madras and Faculty of Environmental Studies, York University. Pages $82-88$.

Chatterjee P. (2004) The Politics of the Governed: Reflections on Popular Politics in Most of the World, New Delhi: Permanent Black.

Colatei D \& B Harriss-White 2004 'Social Stratification in rural households' in B. Harriss-White \& S Janakarajan Rural India facing the $21^{\text {st }}$ Century Anthem

Davis M 2004 Planet of Slums Urban Involution and the Informal Proletariat New Left Review vol 26, pp534

De la Rocha M. G. 2007 The construction myth of survival, Development and Change 38:1 45-66.

Dollar, D. \& A. Kraay (2001). Growth is Good for the Poor. Washington DC, IBRD.

Edward, P. (2006). "Examining Inequality: Who Really Benefits from Global Growth?" World Development, 34(10): 1667-1695.

Ekstrom, M. (1992). "Causal Explanation Of Social-Action - The Contribution Of Weber,Max And Of Critical Realim To A Generative View Of Causal Explanation In Social-Science." Acta Sociologica 35(2): 107-122.

Erb S and B Harriss-White 2003 Outcast from Social Welfare - Adult Disability in South India Banglore Books for Change

Fernandez B 2008 Engendering Poverty Policy in India D Phil Thesis, Oxford University

Fernandez, L. 2004. The Politics of Forgetting: Class Identities, State Power and the Restructuring of Urban Space in India. Urban Studies, 41 (12): 2415-2430.Ghosh J \& C.P. Chandrasekhar 2010 Controlling Food Price Inflation Hindu Business Line February $23^{\text {rd }}$

Gilbert, A. 2007. Return of the slum: does language matter? International Journal of Urban and Regional Research 31, 4, 697-714

Government of India, various years, Census of India New Delhi

Government of India (2006) Population Projections for India and States 2001-2026, Report of the Technical Group on Population Projections Constituted by the National Commission on Population, New Delhi: Office of the Registrar General and Census Commissioner

Government of India 2009 Report on Effect of Economic Slowdown on Employment in India Ministry of Labour and Employment, Labour Bureau, Chandigarh

Government of Tamil Nadu 2003 Tamil Nadu Human Development Report, Esha Beteille Social Science Press New Delhi

Gowan P 2009 Crisis in the heartland New Left Review, 55, 5-29

Guhan S / S Subramanian 2003 India's Development Experience : Selected Writings of S Guhan OUP New Delhi

Harriss-White B 2009, Globalisation, the financial crisis and petty production in India's socially regulated informal economy Global Labour Journal 1,1, 151-76

Harriss-White B 2012, Capitalism and the Common Man' Agrarian South: Journal of Political Economy

Holland S. 2009 The world after Keynes Red Pepper, 163, 22-4 
Hyat T. 2001 Trading Places: Intertemporal Choice, Consumption Dynamics and the Poor D Phil Theis Oxford University

IIPS (International Institute for Population Sciences) (2008) National Family Health Survey III, 2005-6: Tamil Nadu, Mumbai: IIPS http://www.nfhsindia.org/NFHS-3\%20Data/TamilNadu report.pdf

Keen, S. (2011). Debunking Economics - Revised and Expanded Edition: The Naked Emperor Dethroned? $2^{\text {nd }}$ rev. ed., London: Zed

Kabir, A., A. Rahman, et al., 2000. Sickness among the urban poor: A barrier to livelihood security. Journal of International Development, 12, 707-722.

Marx, A \& G. van Hootegem (2007). "Comparative configurational case analysis of ergonomic injuries." Journal of Business Research, 60(5): 522-530.

NCEUS National Commission For Enterprises In The Unorganised Sector (2009) The Challenge of Employment in India An Informal Economy Perspective, Delhi

Olsen W.K., Harriss-White, B. Vera-Sanso P \& V. Suresh 2010, 'The Experience of Slum Dwellers in Chennai under the Economic and Environmental Insults of 2008-9' Work in Press Paper no 4 CSASP, SIAS Oxford http://www.southasia.ox.ac.uk/_data/assets/pdf_file/0011/36587/Oxford_University_CSASP_Work in Progress Paper 4.pdf

Pryer, J., 2003. Poverty and vulnerability in dhaka slums: The urban livelihoods study. Hampshire: Ashgate.

PUCL (People's Union for Civil Liberties) 2010 Fact Finding Report, Report of PUCL Fact Finding Team on Forced Evictions and Rehabilitation of Slum Dwellers in Chennai, People's Union for Civil Liberties, Tamil Nadu and Puducherry, http://www.ids-uva.nl/wordpress/wpcontent/uploads/2011/08/7-PUCL-Report.pdf

Ragin, C. C. (2006). "Set Relations in Social Research: Evaluating Their Consistency and Coverage." Political Analysis 14(3): 291-310.

Ragin, Charles C. (2008a). "Qualitative Comparative Analysis Using Fuzzy Sets (fsQCA)", Ch. in Rihoux, Benoit, Ragin, Charles C., eds. (2008) Configurational Comparative Methods. Qualitative Comparative Analysis (QCA) and Related Techniques. Thousand Oaks and London: Sage, pages $87-121$.

Ragin, C. (2008b). Measurement versus calibration: a set-theoretic approach. The Oxford Handbook of Political Methodology J. Box-Steffensmeiner, H. Brady \&D. Collier. New York, Oxford University Press: 800.

Rajagopal, A. 2001. The violence of commodity aesthetics: hawkers, demolition raids, and a new regime of consumption. Social Text 19(3): 91-113

Reddy D.N. \& C Upendranath 2009 National Rural Employment Guarantee: Issues Concerns and Prospects Paper for the Workshop on Inclusive Development. November, Institute for Human Development / Oxfam India, New Delhi

Revankar, R (1971) The Indian Constitution: A Case Study of Backward Classes Fairleigh Dickinson University Press: Rutherford

Rihoux, B., \& Grimm, H. (2006). Innovative Comparative Methods for Policy Analysis. Beyond the Quantitative-Qualitative Divide. New York: Springer/Kluwer.

Rihoux, B., \&C. C. Ragin., eds. (2008). Configurational Comparative Methods. Qualitative Comparative Analysis (QCA) and Related Techniques. Thousand Oaks and London: Sage.

Sankaran K 2008 'Informal Economy, Own Account Workers and the Law: An Overview' WIEGO Law Pilot Project on the Informal Economy http://wiego.org/sites/wiego.org/files/resources/files/iei_background_paper_oaw_and_law.pdf

Schaffer B 1984 Towards Responsibility - public policy in theory and practice in (eds) E Clay \&B Scahffer Room for Manoeuvre Heinemann

Skocpol, T. (1984). Vision and method in historical sociology. Cambridge; New York, Cambridge University Press.

Snow, D. \&D. Cress (2000). "The Outcome of Homeless Mobilization: the Influence of Organization, Disruption, Political Mediation, and Framing." American Journal of Sociology 105(4): 1063-1104.

Soros G. 2008 The crisis and what to do about it Real-world Economics Review 48 pp 312-318

Stiglitz J (2002). "Employment, Social Justice, and Societal Well-Being." International Labour Review 141(1-2): 9-29. 
Unctad India 2009 The Impact of Global Slowdown on India's Exports and Employment UNCTAD, New Delhi Office. http://wtocentre.iift.ac.in/UNCTAD/11.pdf

Vera-Sanso P (1994) What the Neighbours Say: Gender, Personhood and Power in Two Low-income Settlements of Madras, $\mathrm{PhD}$ Thesis, University of London

Vera-Sanso P (1997) Household composition in Madras' low-income settlements, Review of Development and Change, 2(1): 72-98.

Vera-Sanso P (2004) 'They don't need and I can't give it': filial support in South India in (eds) P Kreager and L Schroder-Butterfill Ageing Without Children: European and Asian Perspectives New York and Oxford: Berghahn

Vera-Sanso P (2010) 'Gender, Urban Poverty and Ageing in India' in (ed) S Chant International Handbook on Gender and Poverty: Concepts, Research and Policy Cheltenham, Edward Elgar

Vera-Sanso (forthcoming a, September 2012) Gender, Poverty and Old Age Livelihoods in Urban South India in an Era of Globalisation, Oxford Development Studies

Vera-Sanso (forthcoming b) Reconceiving the impact of population change: a class and gender based analysis of ageing in poverty in urban South India

WIEGO (Women in the Informal Economy Globalising and Organising) 2009 Impact of the Global Recession on the Working Poor in the Informal Economy http://wiego.org/about_ie/ie_news/EconomicCrises2009.php accessed 11th June 2009. 


\section{APPENDIX ONE : FIELD SURVEYS}

The slums were studied in several stages using mixed methods. After the selection of five slums as detailed in the text, 800 households were selected from the Electoral Registers by systematic sampling with an interval of 12 in the three larger slums (to reach 200 households in each) and an interval of 5 in the two smaller settlements. Missing households were replaced by in situ residents and the few refusals by next-door neighbours. Lead representatives (either the male or female head of household, or the person responsible for running the household, that is the male household head's wife or the daughter or daughter-in-law in female headed households) answered questions about the household that covered marital status, age, caste, religion, family and kin networks, work, incomes, education, tenurial status, rent, rental incomes, access to state subsidized food and support of non-resident parents of the household head and their spouse.

Second, people from 179 households participated in one-to-one semi-structured in-depth interviews with lead representatives which called for information about the settlements they lived in, their family, work and migration work histories, livelihoods, pension access, health care and inter-generational relations. This included a number of revists and continued after completion of the third stage. In the third stage, a further sample of households and economically active individuals from female-headed and male-headed households were chosen from the qualitative sample for an economic survey. ${ }^{47}$ The individuals were chosen to represent a range of ages and occupations in order to ascertain the impact of the period of repeated shocks and hardship on slum dweller's small

\footnotetext{
${ }^{47}$ For the purposes of this paper 'economically active' refers to people in paid work or earning an income.
} 
businesses/self-employment and wage work in the five slums studied. The concept of 'economic circumstances' was explored: in a context of significant poverty and vulnerability -with no safety net to speak of. Slum dwellers understand from direct experience the need to balance income and expenditure, reconcile combinations of assets and liabilities (including loans), and control outlays (and savings may even be conceived as an outlay, especially when compulsory) and expenditures. ${ }^{48}$ When asked to summarise their circumstances as going up, down or staying the same and to provide their measure for such informants referenced one (sometimes two) of the following critical shifts in outcome: capacity to sustain their nutritional intake, loss or build-up of assets, significant shifts in interest rates, significant medical costs, capacity to replace broken items, the need to put more people into the labour market, the cutting of expenditure on daughter's education and becoming dependent on a relative.

\footnotetext{
${ }^{48}$ To explain the question in Tamil we asked unga tharam mela poyerukka, keela erangiyurukka, illa appadiye erukka? Or 'varumaanam in the place of 'porulatharam'.. To ask the question of wage workers we said either : unga velaila yethavadhu maatram irruka, or, unga velai nalla poitrukka, illa yethavadhu vithyasam irruka? To ask the question of self employed people we said either unga viyabarathula yethavadhu maatram irruka, or business nalla poitrukka, illa yethavadhu vithyasam irruka?
} 


\section{Appendix 2 Details of the Fuzzy Variable for Economic Circumstances}

Individual Respondents' Economic Circumstances:

\begin{tabular}{|c|c|c|c|c|c|}
\hline & \multicolumn{2}{|c|}{ WAGE-WORKER } & & \multicolumn{2}{|c|}{ SELF-EMPLOYED } \\
\hline & $\begin{array}{l}\% \text { of } \\
\text { individuals }\end{array}$ & $\begin{array}{l}\text { Number of } \\
\text { individuals }\end{array}$ & & $\begin{array}{l}\% \text { of } \\
\text { Individuals }\end{array}$ & $\begin{array}{l}\text { Number of } \\
\text { Individuals }\end{array}$ \\
\hline $\begin{array}{l}\text { Down down } \\
\text { Down (0) }\end{array}$ & $45 \%$ & 33 & & $24 \%$ & 4 \\
\hline 0.17 & $3 \%$ & 2 & & $24 \%$ & 4 \\
\hline 0.33 & $15 \%$ & 11 & & $18 \%$ & 3 \\
\hline $\begin{array}{l}0.51 \quad \text { (no } \\
\text { change) }\end{array}$ & $19 \%$ & 14 & & $6 \%$ & 1 \\
\hline .67 & $12 \%$ & 9 & & $18 \%$ & 3 \\
\hline .83 & $1 \%$ & 1 & & $12 \%$ & 2 \\
\hline \multirow[t]{2}{*}{$\begin{array}{l}\text { Up up up } \\
(1.0)\end{array}$} & $5 \%$ & 4 & & $0 \%$ & 0 \\
\hline & $100 \%$ & & & $100 \%$ & \\
\hline Subtotal & $\begin{array}{l}\text { Overall, } 0.30 \\
\text { average on a } \\
0-1 \quad \text { scale } \\
\text { with } \mathrm{UP}=1\end{array}$ & 74 & & $\begin{array}{l}\text { Overall, } 0.34 \\
\text { average on a } \\
0-1 \quad \text { scale } \\
\text { with } \mathrm{UP}=1\end{array}$ & 17 \\
\hline Total & & & 91 & & \\
\hline
\end{tabular}


Households' Economic Circumstances:

\begin{tabular}{|c|c|c|c|c|c|}
\hline & \multicolumn{2}{|c|}{ WAGE-WORKER } & & \multicolumn{2}{|c|}{ SELF-EMPLOYED } \\
\hline & $\begin{array}{l}\% \text { of } \\
\text { Households }\end{array}$ & $\begin{array}{l}\text { Number of } \\
\text { Households }\end{array}$ & & $\begin{array}{l}\% \text { of } \\
\text { Households }\end{array}$ & $\begin{array}{l}\text { Number of } \\
\text { Households }\end{array}$ \\
\hline $\begin{array}{l}\text { Down down } \\
\text { Down (0) }\end{array}$ & $55 \%$ & 27 & & $33 \%$ & 3 \\
\hline 0.17 & $6 \%$ & 3 & & 0 & 0 \\
\hline 0.33 & $16 \%$ & 8 & & $33 \%$ & 3 \\
\hline $\begin{array}{ll}0.51 & \text { (no } \\
\text { change) } & \end{array}$ & $4 \%$ & 2 & & $11 \%$ & 1 \\
\hline .67 & $8 \%$ & 4 & & $11 \%$ & 1 \\
\hline .83 & $2 \%$ & 1 & & $11 \%$ & 1 \\
\hline \multirow[t]{2}{*}{$\begin{array}{l}\text { Up up up } \\
\text { (1.0) }\end{array}$} & $8 \%$ & 4 & & 0 & 0 \\
\hline & $100 \%$ & 49 & & $100 \%$ & 9 \\
\hline Subtotal & $\begin{array}{l}\text { Overall, } 0.24 \\
\text { average on a } \\
0-1 \quad \text { scale } \\
\text { with } \mathrm{UP}=1\end{array}$ & 49 & & $\begin{array}{l}\text { Overall, } 0.36 \\
\text { average on a } \\
0-1 \quad \text { scale } \\
\text { with } \mathrm{UP}=1\end{array}$ & 9 \\
\hline Total & & & 58 & & \\
\hline
\end{tabular}

